\title{
Hepatitis B Virus: Update in Management
}

Mohamed Abdelhamed, Reda El Badawy, Mohamed Abdelaziz, Nasser Mousa

\begin{abstract}
Summary
Hepatitis $B$ virus (HBV) infection is a major public health problem worldwide. HBV, a member of the hepadnaviridae family, is a small DNA replicates through an RNA intermediate and can integrate into the host genome. It is transmitted through contact with infected blood and semen. HBV infection leads to a wide spectrum of liver disease ranging from acute - fulminant hepatic failure to chronic hepatitis, cirrhosis, and hepatocellular carcinoma. Infants and children are more likely to develop a chronic hepatitis $B$ infection, while most adults infected with the virus recover even if their signs and symptoms are severe, but $5 \%$ $10 \%$ are unable to clear the virus and become chronically infected. Screening for HBV infection could identify chronically infected persons who may benefit from treatment or other interventions, such as surveillance for hepatocellular carcinoma. Most people diagnosed with chronic hepatitis $B$ infection need treatment for the rest of their lives. The primary treatment goals for patients with $\mathrm{HBV}$ infection are to prevent progression of the disease to cirrhosis, liver failure, and hepatocellular carcinoma. Moreover, prevents infection from passing to others. Treatment for chronic hepatitis B may include several antiviral medications such as, entecavir, tenofovir, lamivudine, adefovir and telbivudine. These drugs can help fight the virus and slow its ability to damage your liver. WHO recommends that all infants receive the hepatitis $B$ vaccine as soon as possible after birth, preferably within 24 hours?
\end{abstract}

Keywords: Hepatitis B virus, Nucleoside/nucleotide analogues and hepatitis $B$ vaccine
Medical Journal of Viral Hepatitis

(MJVH) 2019; 3 (2) - pp. 49-56

Received: $13 / 11 / 2018$

Revised: 11/2/2019

Accepted: 20/2/2019

Published Online: 25/4/2019

(Mohamed Abdelhamed, Reda El Badawy) Hepatology dept., Gastroenterology \& infectious disease, Faculty of Medicine, Benha Univ., Egypt (Mohamed Abdelaziz, Nasser Mousa) Tropical Medicine dept., Faculty of Medicine, Mansoura Univ., Egypt

* CA: Mohamed Abdelaziz

dr.mohammed860a@yahoo.com

\section{Introduction}

Infection with hepatitis B virus (HBV) remains an important global public health problem with significant morbidity and mortality ${ }^{1}$. The prevalence of chronic HBV infection is highest in the Western Pacific $(6.2 \%)$ and African regions (6.1\%). The Eastern Mediterranean region has high prevalence $(3.3 \%)$; the prevalence is lower in the South-East Asian (2.0\%) and European regions $(1.6 \%)$ and is lowest in the North and South American regions $(0.7 \%)^{2}$. The prevalence is decreasing in several endemic countries due to improvements in the socioeconomic status, universal vaccination programs and perhaps effective antiviral treatments ${ }^{3}$. There are ten different genotypes of HBV (A-J), and the geographical distribution of each HBV genotype is distinct. Infection with different genotypes of
HBV is associated with different outcomes in chronicity, disease progression and responses to IFN $\alpha$ treatment; however, the approved HBV vaccines are effective against all genotypes ${ }^{4}$.

\section{Natural history of HBV infection}

New terminology has been suggested for the phases of chronic HBV infection. The previously used terms of immune tolerance, immune active and/or clearance and immune control and/or residual phases have been changed. HBV infection can be classified now into five phases, Tab. (1): (I) HBeAg-positive chronic infection, (II) $\mathrm{HBeAg}$-positive chronic hepatitis, (III) $\mathrm{HBeAg}$-negative chronic infection, (IV) HBeAg-negative chronic hepatitis and (V) HBs Ag-negative phase ${ }^{5}$. 
Phase 1: HBeAg-positive chronic HBV infection.

Previously named immune tolerance phase. This phase (also termed the high replicative, low inflammatory phase) typically occurs in patient infected perinatally. It is characterized by high viral load, near normal liver histology owing to a minimal host immune mediated reaction, ALT persistently within the normal range according to traditional cut-off values [upper limit of normal approximately $40 \mathrm{IU} / \mathrm{L}$ ] and serum positivity for $\mathrm{HBeAg}^{6}$. Recent studies have indicated that adolescents may have detectable HBV-specific functionally active T cells. Studies of this phase of the disease have also revealed clonal expansion of hepatocytes and visible $\mathrm{HBV}$ integrands ${ }^{7}$, which may contribute to the development of HCC by trans activeting human oncogenes. These patients are highly infectious owing to the high levels of HBV DNA.

\section{Phase 2: HBeAg-positive chronic hep- atitis $B$.}

The second phase, historically termed immune clearance or immune active phase, most commonly occurs in the third or fourth decade of life in patients who were infected with HBV at an early age. The prominent features of this phase are the presence of serum $\mathrm{HBeAg}$, high levels of HBV DNA and elevated ALT and presence of moderate-severe liver necroinflammation ${ }^{6}$. In this phase, the triggering of immune $\mathrm{T}$ cell-mediated responses against infected hepatocytes leads to the cytolytic release of alanine transaminases (ALT) and reduction of HBV DNA levels. However, the intensity of the immune response fluctuates over time, resulting in fluctuating levels of ALT (hepatitis flares, which are defined differently in different studies; for example, twofold elevation from the baseline ALT levels and HBV $\mathrm{DNA}^{8}$. This phase can be of varying duration and ends with a reduction of HBV DNA level and $\mathrm{HBe} \mathrm{Ag}$ seroconversion to anti-HBe positivity and enter the HBeAg-negative infection phase in majority of patients. Other patients may fail to control $\mathrm{HBV}$ and progress to the $\mathrm{HBe}$ Ag-negative CHB phase for many years ${ }^{5}$.

\section{Phase 3: HBeAg-negative chronic HBV} infection.

A proportion of patients (annual rate of $\sim 15 \%$ ) will spontaneously seroconvert from $\mathrm{HBeAg}$ to anti-HBe; these patients (previously referred to as inactive carriers) typically show absence of serum $\mathrm{HBeAg}$ with detectable anti-HBe, near normal serum aminotransferases and HBV DNA concentrations of $<2,000 \mathrm{IU}$ per $\mathrm{ml}^{6}$. Certain patients in this phase, still have HBV DNA levels $>2,000 \mathrm{IU} / \mathrm{ml}$ however $<20,000 \mathrm{IU} / \mathrm{ml}$ ) associated with persistently normal ALT and only minimal hepatic necroinflammatory activity and low fibrosis. These patients have low risk of progression to cirrhosis or HCC if they remain in this phase ${ }^{6}$. In a substantial proportion of patients in Asian and Mediterranean countries, $\mathrm{HBeAg}$ seroconversion is associated with the occurrence of precore and/or core promoter mutations ${ }^{9}$. In these patients, $\mathrm{HBeAg}$ is absent because of the selection of $\mathrm{HBV}$ virions that do not express $\mathrm{HBeAg}$ (precore mutant HBV). Finally, patients may have spontaneous HBsAg sero clearance during the natural course of disease. Various studies have shown that patients with spontaneous HBsAg seroclearance at an earlier age have a better outcome than those without HBsAg seroclearance ${ }^{10}$.

Phase 4: Named HBeAg-negative chronic hepatitis $B$.

It is characterised by the absence of serum $\mathrm{HBe}$ Ag usually with detectable anti-HBe, and persistent or fluctuating moderate to high levels of serum HBV DNA (often lower than in HBeAgpositive patients), in addition to fluctuating or persistently elevated ALT values. The liver histology shows necroinflammation and fibrosis. The majority of these patients harbour HBV variants in the precore and/or the basal core promoter regions that abate or stop $\mathrm{HBeAg}$ expression. This phase is associated with low rates of spontaneous disease remission ${ }^{6}$.

\section{Phase 5: HBsAg-negative phase}

It is characterised by serum negative $\mathrm{HBsAg}$ and positive antibodies to $\mathrm{HBcAg}$ (anti-HBc), with or without detectable antibodies to $\mathrm{HBsAg}$ (anti-HBs). This phase is also known as "occult HBV infection". In rare cases, the absence of HBsAg could be related to the sensitivity of the assay used for detection ${ }^{11}$. Patients in this phase have normal ALT values and usually, but not always, undetectable serum HBV DNA. HBV DNA (cccDNA) can be detected frequently in the liver ${ }^{6}$. HBsAg loss before the onset of cirrhosis is associated with a minimal risk of cirrhosis, decompensation and HCC, and an improvement on survival. However, if cirrhosis has developed before HBsAg loss, patients 
remain at risk of $\mathrm{HCC}$ therefore, $\mathrm{HCC}$ surveyllance should continue. Immunosuppression may lead to HBV reactivation in these patients. Table (1) Natural history of patients with chronic HBV infection.

\begin{tabular}{|l|c|c|c|c|}
\hline \multirow{2}{*}{} & \multicolumn{2}{|c|}{ HBeAg positive } & \multicolumn{2}{c|}{ HBeAg negative } \\
\cline { 2 - 5 } & $\begin{array}{c}\text { Chronic } \\
\text { infection }\end{array}$ & $\begin{array}{c}\text { Chronic } \\
\text { hepatitis } \\
\text { High/intermediate }\end{array}$ & $\begin{array}{c}\text { Chronic } \\
\text { infection }\end{array}$ & $\begin{array}{c}\text { Chronic } \\
\text { hepatitis }\end{array}$ \\
\hline HBsAg & High & Intermediate \\
\hline HBeAg & Positive & Positive & Negative & Negative \\
\hline HBVDNA & $>107 \mathrm{IU} / \mathrm{ml}$ & $104-107 \mathrm{IU} / \mathrm{ml}$ & $<2,000 \mathrm{IU} / \mathrm{ml}$. & $>2,000 \mathrm{IU} / \mathrm{ml}$ \\
\hline ALT & Normal & Elevated & Normal & Elevated* \\
\hline Liver disease & None/minimal & Moderate/severe & None & Moderate/severe \\
\hline Old terminology & $\begin{array}{c}\text { Immune } \\
\text { tolerant }\end{array}$ & $\begin{array}{c}\text { Immune reactive } \\
\text { HBeAg positive }\end{array}$ & Inactive carrier & $\begin{array}{c}\text { HBeAg negative } \\
\text { chronic hepatitis }\end{array}$ \\
\hline
\end{tabular}

*Persistently or intermittently. ${ }^{\circ 0} \mathrm{HBV}$ DNA levels can be between 2,000 and 20,000 IU/ml in some patients without sings of chronic hepatitis.

\section{Diagnosis, Screening and Prevention Diagnosis}

The key serological marker of acute and chronic hepatitis B is the detection of HBsAg in serum. However, several other HBV serological markers are clinically useful in HBV infection. For example, in patients with clinical recovery of $\mathrm{HBV}$ infection, anti-HBs and hepatitis $\mathrm{B}$ core antigen $(\mathrm{HBc} \mathrm{Ag}$; anti-HBc) may be detectable, tab. (2). In addition to serum tests, an assessment of the fibrosis and cirrhosis status in patients with chronic HBV infection is also important for disease prongostication, treatment indication and management. An accurate but invasive test of liver disease is liver biopsy, whereas noninvasive tests include transient elastography (to measure liver stiffness) or various serum biomarkers. With the availability of the latter two methodologies, most patients and clinicians are reluctant to go through with liver biopsy because of its invasive nature. Algorithms for the use of serum biomarkers and liver stiffness measurements (if transient elastography is available) can be used in clinical practice to adjudge the degree of fibrosis in chronic hepatitis $\mathrm{B}^{12}$.

Detection of HBsAg and HBsAg-specific antibodies

Detection of HBsAg in serum is the standard serological test to confirm HBV infection ${ }^{13}$. Chronic HBV infection is diagnosed by a repeat positive test for $\mathrm{HBsAg}, 6$ months after the first positive test. By contrast, after recovery from acute HBV infection, the levels of HBsAg become undetectable. HBsAg concentrations differ during the varying longitudinal phases of disease and are generally higher in individuals with detectable $\mathrm{HBeAg}^{14}$. Importantly, $\mathrm{HBsAg}$ remains measurable when serum HBV DNA falls to undetectable levels by sensitive PCR. Moreover, quantitative measurement of $\mathrm{HBsAg}$ has prognostic importance and has been incorporated into risk scores to predict the risk of $\mathrm{HCC}$, and may indicate the risk of viral rebound after stopping NUCs ${ }^{15}$. A positive test result for anti-HBs in patients who tested negative for $\mathrm{HBsAg}$ can be associated with a response to $\mathrm{HBV}$ vaccination, recovery from acute hepatitis or $\mathrm{HBsAg}$ seroconversion in chronic $\mathrm{HBV}$ infection.

\section{Detection of $\mathrm{HBeAg}$}

$\mathrm{HBeAg}$ serological testing, usually performed in chronic HBV-infected patients, distinguishes two forms of hepatitis B: HBeAg-positive and $\mathrm{HBe} A g$-negative chronic $\mathrm{HBV}$ infection. $\mathrm{HBe}$ $\mathrm{Ag}$ seroconversion marks the transition from the immune clearance phase or HBeAg-positive chronic hepatitis to the immune control phase or HBeAg-negative chronic infection or hepatitis ${ }^{5}$. Detection of anti-HBc

Total anti-HBc measured by immunoassay is a marker of acute, chronic and resolved HBV infection, or occult hepatitis B. In addition, the presence of anti-HBc can predict reactivation of HBV associated with rituximab or immunosuppressive therapy. Immunoglobulin M (IgM) anti-HBc is detected during acute HBV infection and is also detected during exacerbations of chronic HBV, and importantly, it may be the only serological marker detectable in fulminant acute hepatitis B. Thus, measurement of anti$\mathrm{HBc}$ is usually recommended for diagnosis in patients suspected to have an acute exacerbation of chronic HBV infection or to decide if patients who are planning to undergo immunosuppressive therapy will require prophylactic antiviral therapy ${ }^{16}$.

\section{Detection of HBV DNA}

HBV DNA tests should be performed on a regular basis (every 6 months) in all patients with chronic HBV. The concentrations of HBV DNA provide an indication for therapy within current guidelines ${ }^{15}$, and for monitoring treatment efficacy. Indications for treatment are based on the association between HBV DNA concentrations and the risk of HCC.A decline in HBV DNA concentrations can predict the efficacy of treatment, and an increase in HBV DNA in serum is observed with the development of resistance to $\mathrm{NUCs}^{16}$. 


\section{Co-morbidities}

It including other causes of chronic liver disease should be systematically excluded including co-infections with hepatitis D virus (HDV), hepatitis $\mathrm{C}$ virus (HCV) and HIV.

\section{Testing for antibodies}

Testing for antibodies against hepatitis A virus should be performed, and patients with negative anti-HAV should be advised to be vaccinated against HAV.

Table (2) Interpretation of screening tests for HBV infection

\begin{tabular}{|c|c|c|c|c|}
\hline \multicolumn{4}{|c|}{ Serologic Marker } & \multirow[b]{2}{*}{ Interpretation } \\
\hline HBsAg & $\begin{array}{c}\text { Total } \\
\text { Anti-HBc }\end{array}$ & $\begin{array}{c}\mathrm{IgM} \\
\text { Anti-HBc }\end{array}$ & Anti-HBs & \\
\hline- & - & - & - & Never infected, but susceptible to infection, \\
\hline+ & - & - & - & $\begin{array}{l}\text { Early acute infection; transient (up to } 18 \text { days) after } \\
\text { vaccination }\end{array}$ \\
\hline+ & + & + & - & Acute infection \\
\hline- & t & + & - & Acute resolving infection \\
\hline- & + & - & + & Past infection, recovered and immune \\
\hline+ & t & - & - & Chronic infection \\
\hline - & + & - & - & $\begin{array}{l}\text { Interpretation unclear, } 4 \text { possibilitities:1. False-positive } \\
\text { anti-HBc thus susceptible } 2 \text {. Resolved infection (most } \\
\text { common) 3. Low-level chronic infection 4. Resolving acute } \\
\text { infection }\end{array}$ \\
\hline - & - & - & + & $\begin{array}{l}\text { Immune due to hepatitis } B \text { vaccination if } \\
\text { concentration is } \geq 10 \mathrm{mIU} / \mathrm{mL}\end{array}$ \\
\hline
\end{tabular}

$\boldsymbol{H B} \boldsymbol{s} \boldsymbol{A g}=$ hepatitis $B$ surface antigen; $\boldsymbol{a n t i - H B c}=$ antibody to hepatitis $B$ core antigen; anti-HBs= antibody to HBsAg; $\mathbf{I g M}=$ immunogl-obulin $M$; $\mathbf{m I U} / \mathbf{m L}=$ milli-International Units per milliliter .

\section{HBV Vaccine Indications}

The WHO recommends universal vaccination for HBV and that all infants should receive the first dose of vaccine soon after birth, preferably within 24 hours. The birth dose, or vaccination within the expanded programme on immunization (EPI) dose, is followed by an additional two to three doses, depending upon national policies and prevalence, tab. (3).

Table (3) High-risk unvaccinated individuals for which hepatitis B vaccine is recommended ${ }^{17}$.

- All infants, beginning at birth

- All children aged $<19$ years who have not been vaccinated previously

- Susceptible sexual partners of hepatitis B-positive persons

- Sexually active pers ons who are not in a long-term, mutually monogamous relationship

(e.g., >1 sex partner during the previous 6 months)

- Persons seeking evaluation or treatment for a sexually transmitted disease

- Men who have sex with men

- Injection drug users

- Susceptible household contacts of hepatitis B-positive person

- Healthcare and public safety workers at risk for exposure to blood

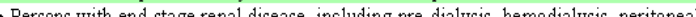

dialysis, and home dialysis patients

- Residents and staff of facilities for developmentally disabled persons

- Travelers to and families adopting from countries where hepatitis B is common (e.g

Asia, Africa, South America, Pacific Islands, Eastern Europe, and the Middle East)

Persons with chronic liver disease, other than hepatitis B (e.g. cirrhosis, fatty liver

disease, etc.)

- Persons with hepatitis $\mathrm{C}$ infection

- Persons with HIV infection

- Adults with diabetes aged 19 through 59 years (clinicians can decide whether or

not to vaccinate their diabetic patients $\geq 60$ years)

- All other persons seeking protection from HBV infection - acknowledgment of a

specific risk factor is not a requirement for vaccination

\section{Goals of therapy}

The ultimate goal is total eradication of HBV infection by various strategies, including vaccination, treatment and prevention of transmission. The goal of therapy for chronic HBV infection is to improve quality of life and survival of the infected person via preventing progression of the disease to cirrhosis, decompensated cirrhosis, end-stage liver disease, $\mathrm{HCC}$ and death. Also to prevent transmission of HBV to others, hepatitis B reactivation and the prevention and treatment of $\mathrm{HBV}$-associated extrahepatic manifestations ${ }^{5,18}$. This goal can be achieved by suppression of HVB replication in sustained manner. Regression of fibrosis and cirrhosis can be regarded as a further goal of treatment in patients with established advanced fibrosis or cirrhosis. In patients with HBVinduced $\mathrm{HCC}$, the goals of nucleos(t)ide analogue (NA) therapy are primarily to suppress $\mathrm{HBV}$ replication to induce the stabilization of $\mathrm{HBV}$-induced liver disease and to prevent disease progression, and to reduce the risk of $\mathrm{HCC}$ recurrence after potentially curative HCC therapies. Stabilizing the HBV-induced liver disease can be also regarded as a prerequisite for the safe and effective applications of HCC treatments ${ }^{5}$.

\section{End points of treatment}

HBV treatment is typically aimed to achieve profound virological suppression, which in turn will lead to biochemical remission (return of ALT values to the normal range), histological improvement and prevention of the complications of liver disease. The ideal endpoint in both $\mathrm{HBeAg}$-positive and $\mathrm{HBeAg}$ - negative patients is sustained off-therapy HBsAg loss, with or without seroconversion to anti-HBs. This is associated with a complete and definitive remission of the activity of CHB and an improved long-term outcome. This endpoint, however, is infrequently achievable with the currently available anti-HBV agents. A more realistic endpoint is the induction of sustained or maintained virological remission ${ }^{19}$. Induction of sustained off-therapy virological response in both $\mathrm{HBeAg}$-positive (with sustained anti$\mathrm{HBe}$ seroconversion) and $\mathrm{HBeAg-negative} \mathrm{pat-}$ ients is a satisfactory endpoint, because it has been shown to be associated with improved prognosis. If sustained off-therapy response not ach- 
ievable, then a maintained virological remission (undetectable HBVDNA by a sensitive PCR assay) under long-term antiviral therapy in $\mathrm{HBe}$ Ag-positive patients who do not achieve anti$\mathrm{HBe}$ seroconversion and in $\mathrm{HBeAg-negative}$ patients is the next most desirable endpoint ${ }^{18}$. A more advanced functional cure is $\mathrm{HBsAg}$ seroclearance, as spontaneous or treatment associated HBsAg seroclearance substantially decreases the risk of $\mathrm{HCC}$ development, provided the patient is $<50$ years of age $\mathrm{a}^{\mathbf{2 0}}$, and has not developed cirrhosis. However, HBsAg seroclearance is rarely achieved with the currently available anti-HBV agent's. Current potent NUCs have a profound effect on virological suppression with continued therapy. For NUCs: a virological response is defined as undetectable serum HBV DNA (10-60 IU per ml); a serological response as $\mathrm{HBe} \mathrm{Ag}$ and/or $\mathrm{HBsAg}$ seroconversion; a biochemical response as normalization of serum ALT level; and a histological response as a decrease in necroinflammation of the liver ${ }^{5}$. Worldwide, Pegylated interferon- $\alpha$ (PEG-IFN $\alpha$ ) therapy is given for a finite duration to a small subset of patients (discussed below) with the aim of achieving sustained off-treatment immune control. The response is assessed 6 months post-treatment, with criteria similar to those of NUCs, except for the virological response, which is defined as HBV DNA <2,000 IU per ml.Long-term follow-up studies of sustained treatment with NUCs demonstrate that a profound reduction in development of cirrhosis can be achieved with the early initiation of treatment. Consequently, this has resulted in an almost complete elimination of liver failure in the setting of treated patients with chronic HBV infection. In addition, there is a clear reduction, but not complete prevention, of the development of $\mathrm{HCC}^{21}$.

\section{Treatment Agents}

Treatment agents approved by the US FDA, European Medicines Agency and many countries in Asia are broadly classified into immunomodulatory agents and antiviral agents, tab. (4). The former includes conventional IFN $\alpha-2 b$ and PEG-IFN $\alpha-2 a$. The latter includes (nucleoside/ nucleotide analogues) NUCs, namely:

*) Lamivudine (LAM)

*) Adefovir dipivoxil (ADV)
*) Entecavir (ETV)

*) Telbivudine, (TDF)

*) Tenofovir alafenamide (TAF).

The mainstay of treatment in most countries is NUCs. Of the six NUCs licensed by FDA for HBV treatment, ETV, TDF and TAF are the advocated first-line agents because of their potency and low resistance rates. Entecavir has negligible adverse effects and is an excellent agent for treatment-naive patients. However, patients previously treated with lamivudine who have developed lamivudine resistance will already have two of the three mutations required for the development of entecavir resistance; $51 \%$ of these individuals will develop entecavir resistance within 5 years ${ }^{22}$. In lamivudine- resistant patients, TDF and TAF are the best treatment options. Compared with TDF, TAF can achieve a higher intrahepatic level of tenofovir; thus, a lower dose of TAF can be used to exert the same degree of viral suppression. As such, the off-target effects of TAF are decreased ${ }^{23}$. According to one study, TAF has comparable viral suppression to TDF with improved rates of ALT normalization, substantially fewer declines in hip and spine bone mineral density (side effect of TDF) and smaller decreases in estimated glomerular filtration rate, indicating TAF has less of an off-target effect on renal function $^{24}$. However, in general, clinical adverse effects are considered to be minimal during long-term NUC therapy.

Table (4) Approved HBV antiviral therapy in children and adults ${ }^{25}$.

\begin{tabular}{|c|c|c|c|c|}
\hline Drug & $\begin{array}{l}\text { Dose in } \\
\text { Adults* } \\
\end{array}$ & Use in Children ${ }^{+}$ & $\begin{array}{l}\begin{array}{l}\text { Pregnancy } \\
\text { Category }\end{array} \\
\end{array}$ & Potential Side Effects ${ }^{\dagger}$ \\
\hline \multicolumn{5}{|l|}{ Prefented } \\
\hline $\begin{array}{l}\text { Peg-IFN-a-2a (adult) } \\
\text { IFN- } a_{\star} 2 \mathrm{~b} \text { (children) }\end{array}$ & $\begin{array}{l}180 \mathrm{mcg} \\
\text { weekly }\end{array}$ & $\begin{array}{l}\geq 1 \text { year dose: } 6 \\
\text { million IU/m2 three } \\
\text { times weekly } \$\end{array}$ & c & $\begin{array}{l}\text { Flu-like symptoms, fatigue, } \\
\text { mood disturbances, cytopenia, } \\
\text { autoimmune disorders in adults, } \\
\text { anorexia and weight loss in } \\
\text { children }\end{array}$ \\
\hline Entecavir & $\begin{array}{l}0.5 \mathrm{mg} \\
\text { dailyle }\end{array}$ & $\begin{array}{l}\geqslant 2 \text { years doce: : weight- } \\
\text { based to } 10-30 \mathrm{~kg} \\
\text { above } 30 \mathrm{~kg}: 0.5 \mathrm{mg} \\
\text { dailyla }\end{array}$ & $\mathrm{c}$ & $\begin{array}{l}\text { Lactic acidosis (decompensated } \\
\text { cirnosis only) }\end{array}$ \\
\hline $\begin{array}{l}\text { Tenofovir dipovoxil } \\
\text { fumarate }\end{array}$ & $\begin{array}{c}300 \mathrm{mg} \\
\text { daily }\end{array}$ & $\geq 12$ years & B & $\begin{array}{l}\text { Nephropathy, Fanconi synd- } \\
\text { rome, osteomalacia, lactic } \\
\text { acidosis }\end{array}$ \\
\hline Tenofovir alafenamide & $\begin{array}{l}25 \mathrm{mg} \\
\text { daily }\end{array}$ & - & $\begin{array}{l}\text { There are insuffi- } \\
\text { cient human data } \\
\text { on use curing pre- } \\
\text { gnancy to inform } \\
\text { a drug-associated } \\
\text { risk of birth defects } \\
\text { and miscarriage. }\end{array}$ & Lactic acidosis \\
\hline \multicolumn{5}{|l|}{ Non preferred } \\
\hline Lamivudine & $\begin{array}{c}100 \mathrm{mg} \\
\text { daily }\end{array}$ & $\begin{array}{c}\geq 2 \text { years dose: } 3 \\
\mathrm{mg} / \mathrm{kg} \text { daily to } \mathrm{max} \\
100 \mathrm{mg}\end{array}$ & c & Pancreatitis Lactic acidosis \\
\hline Adefovir & $\begin{array}{l}10 \mathrm{mg} \\
\text { daily }\end{array}$ & $\geq 12$ years & $\mathrm{C}$ & $\begin{array}{l}\text { Acute renal failure, Fanconi } \\
\text { syndrome, Lactic acidosis }\end{array}$ \\
\hline Telbivudine & $\begin{array}{l}600 \mathrm{mg} \\
\text { daily }\end{array}$ & - & B & $\begin{array}{l}\text { Creatine kinase elevation and } \\
\text { myopathy Peripheral neurop- } \\
\text { athy Lactic acidosis }\end{array}$ \\
\hline \multicolumn{5}{|c|}{$\begin{array}{l}\text { *Dose adjustments are needed in patients with } \\
\text { renal dysfunction. IIn } 2015 \text {, the U.S. Food and } \\
\text { Drug Administration replaced the pregnancy risk } \\
\text { designation by letters } A, B, C, D \text {, and X with more } \\
\text { specific language on pregnancy and lactation. } \\
\text { This new labeling is being phased in gradually, }\end{array}$} \\
\hline
\end{tabular}


and to date only TAF includes these additional data. \$Peg-IFN-a-2a is not approved for children with chronic hepatitis $B$, but is approved for treatment of chronic hepatitis $C$. Providers may consider using this drug for children with chronic $H B V$. The duration of treatment indicated in adults is 48 weeks. ${ }^{\circledR}$ Entecavir dose is $1 \mathrm{mg}$ daily if the patient is Lamivudine experienced or if they have decompensated cirrhosis. Abbreviation: $\mathrm{TSH}$, thyroid stimulating hormone.

\section{Indications of treatment}

The indications for treatment are based largely on the combination of three criteria:

- Serum HBV DNA levels

- Serum ALT levels

- Severity of liver disease (assessed by clinical evaluation, liver biopsy or noninvasive methods).

Indications for treatment should also take into account age, health status, family history of HCC or cirrhosis and extrahepatic manifestations, tab. $(5)^{5,18,25}$.

Table (5) Indications for initiating treatment in chronic HBV infection.

\begin{tabular}{|c|c|c|c|c|}
\hline \multirow{2}{*}{ Guideline } & \multicolumn{2}{|c|}{$\begin{array}{c}\text { Individuals who are HBeAg } \\
\text { positivea }\end{array}$} & \multicolumn{2}{c|}{$\begin{array}{c}\text { Individuals who are HBeAg } \\
\text { negativea }\end{array}$} \\
\cline { 2 - 5 } & $\begin{array}{c}\text { HBV DNA } \\
\text { IU/ml }\end{array}$ & ALT U/ & $\begin{array}{c}\text { HBV DNA } \\
\text { IU/ml }\end{array}$ & ALT U/ \\
\hline \multirow{2}{*}{ EASL5 2017 } & $\geq 2,000$ & $\begin{array}{l}>\text { ULN and/or at least } \\
\text { moderate liver necroi- } \\
\text { nflammation of fibrosis }\end{array}$ & $\geq 2,000$ & $\begin{array}{c}>\text { ULN and/or at least } \\
\text { moderate liver necroi- } \\
\text { nflammation of fibrosis }\end{array}$ \\
\cline { 2 - 5 } & $\geq 20,000$ & $\begin{array}{l}>2 \times \text { ULN irrespective } \\
\text { of fibrosis }\end{array}$ & $\geq 20,000$ & $\begin{array}{l}>2 \times \text { ULN irrespective } \\
\text { of fibrosis }\end{array}$ \\
\hline AASLD25 2016 & $>20,000$ & $\begin{array}{l}>2 \times \text { ULN or significant } \\
\text { histological disease }\end{array}$ & $>2,000$ & $\begin{array}{l}>2 \times \text { ULN or significant } \\
\text { histological disease }\end{array}$ \\
\hline APASL18 2015 & $\geq 20,000$ & $\begin{array}{l}>2 \times \text { ULN or significant } \\
\text { histological disease }\end{array}$ & $\geq 2,000$ & $\begin{array}{l}>2 \times \text { ULN or significant } \\
\text { histological disease }\end{array}$ \\
\hline
\end{tabular}

AASLD, American Association for the Study of Liver Diseases; ALT, alanine aminotransferase; APASL, Asian Pacific Association for the Study of Liver; EASL, European Association for the Study of the Liver; HBeAg, hepatitis $B$ e antigen; $\boldsymbol{H B V}$, hepatitis $B$ virus; $\boldsymbol{I U}$, international units; $\boldsymbol{U L N}$, upper limit of normal. A patient with cirrhosis with detectable HBV DNA should be treated irrespective of the HBV DNA and ALT levels.

Although, the liver biopsy is still to be the gold standard to estimate disease activity in $\mathrm{CHB}^{26}$, the treatment decisions may be based on non-invasive markers of fibrosis. Elastography is seemed to have the highest diagnostic accuracy for the detection of advanced fibrosis. The results of elastography should be interpreted with caution in patients with severe inflammation and high ALT levels ${ }^{27}$. Patients with HBV DNA levels > $20000 \mathrm{IU} / \mathrm{mL}$ and ALT $>2 x U L N$ can begin treatment without a liver biopsy because usually the results will not change the decision for treatment ${ }^{25}$. A non- invasive technique is recommended in these cases to confirm or exclude cirrhosis in patients who begin treatment without a liver biopsy ${ }^{27}$. Treatment may be begun in patients with HBV DNA levels $>2000 \mathrm{IU} / \mathrm{mL}$ and at least moderate fibrosis, even if ALT levels are normal. In addition, patients with $\mathrm{HBeAg}$-positive chronic HBV infection (persistently normal ALT and high HBV DNA levels) may be treated if they are $>30$ years old whatever the severity of histological lesions in the liver ${ }^{25}$. Since the course of chronic HBV infection fluctuates, patients who do not fulfill the indications for antiviral therapy should be carefully monitored with periodic assessment of serum ALT and HBV DNA levels as well as for the severity of liver fibrosis by non-invasive markers. Patients with $\mathrm{HBeAg}$-positive chronic $\mathrm{HBV}$ infection who are $<30$ years old and not being treated should undergo ALT tests every 3 months at least, HBV DNA every 6-12 months and assessment of liver fibrosis every 12 months ${ }^{25}$. Patients with $\mathrm{HBeAg-negative} \mathrm{chronic} \mathrm{HBV}$ infection and HBV DNA <2000 IU/mL should be monitored with ALT measurements every 6-12 months and periodic HBV DNA and liver fibrosis tests every 2-3 years ${ }^{28}$. Recent data suggest that, quantitative HBsAg testing can be helpful in deciding on the frequency of follow-up in such patients. Patients with HBsAg levels < $1000 \mathrm{IU} / \mathrm{mL}$ should undergo ALT measurements every 12 months and have HBV DNA and liver fibrosis tests every 3 years, while those with HBsAg levels $\geq 1000 \mathrm{IU} / \mathrm{mL}$ should receive ALT measurements every 6 months and HBV DNA and liver fibrosis tests every 2 years at least ${ }^{25}$. Patients with HBeAgnegative chronic $\mathrm{HBV}$ infection, normal ALT and HBV DNA $\geq 2000 \mathrm{IU} / \mathrm{mL}$ should be closely followed with ALT measurements every 3 months for the first year and every 6 months at least thereafter. Moreover, annual evaluation of HBV DNA levels and a non-invasive liver fibrosis test should be performed for at least 3 years. If they do not fulfil any indications for treatment during the first 3 years of follow-up, these patients should be monitored for life, like all other patients in this phase of disease $^{\mathbf{2 6}}$. Patients with decompensated cirrhosis and detectable HBV DNA, tab. (6) require urgent antiviral treatment with NA(s). Significant clinical improvement can be associated with control of viral replication ${ }^{29,30}$. However, the 
patients should be considered for liver transplantation at the same time if antiviral treatment not sufficient to correct the decompensating state $^{18}$. Patients with compensated cirrhosis and HBV DNA > $2000 \mathrm{U} / \mathrm{ml}$ should also be considered for treatment even if ALT levels are normal $^{18}$

Table (6) Treatment indications for chronic HBV-infected patients with cirrhosis or reactivation of chronic HBV infection $^{18}$.

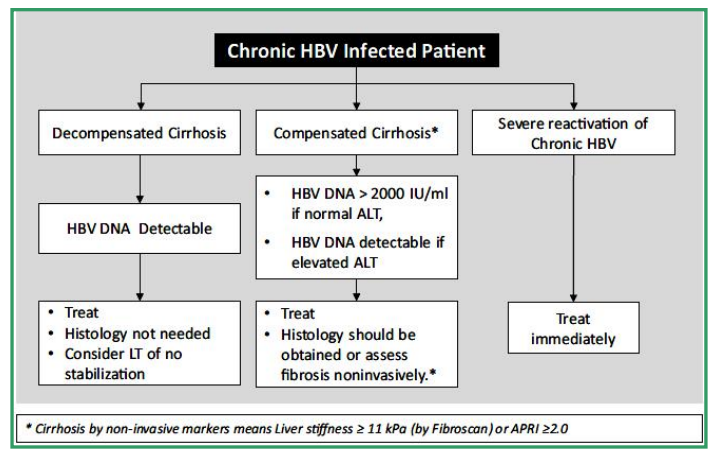

\section{References}

1- Schweitzer A, Horn J, Mikolajczyk R, Krause G, Ott J. Estimations of worldwide prevalence of chronic hepatitis B virus infection: A systematic review of data published between 1965 and 2013. Lancet 2015; 386: 1546-1555.

2- World Health Organization. Global Hepatitis Report. WHO, Geneva, 2017.

3- Chen L, Yang Y, Lin F, Sun A, Bai H, You L, et al. Slow decline of hepatitis B burden in general population: Results from a population-based survey and longitudinal follow-up study in Taiwan. J. Hepatol. 2015; 63: 354-363.

4- Sunbul M. Hepatitis B virus genotypes: global distribution and clinical importance. World. Gastroenterol. 2014; 20 (18): 54275434

5- European Association for the Study of the Liver. EASL 2017 Clinical practice guidelines on the management of hepatitis B virus infection. J. Hepatol. 2017; 67: 370398.

6- European Association for the Study of the Liver. EASL clinical practice guidelines: Management of chronic hepatitis B virus infection. J. Hepatol. 2012; 57: 167-185.

7- Mason S, Gill S, Litwin S, Zhou Y, Peri $\mathrm{S}$, Pop $\mathrm{O}$, et al. HBV DNA integration and clonal hepatocyte expansion in chronic hepatitis B patients considered immune tolerant. Gastroenterology 2016; 151 (5): 986-998.e4.

8- Yuen M, Sablon E, Hui C, Li T, Yuan H, Wong D, et al. Prognostic factors in severe exacerbation of chronic hepatitis B. Clin. Infect. Dis. 2003; 36: 979-984.

9- Yuan HJ, Ka-Ho Wong D, Doutreloigne J, Sablon E, Lai L, Yuen F. Precore and core promoter mutations at the time of $\mathrm{HBeAg}$ seroclearance in Chinese patients with chronic hepatitis B. J. Infect. 2017; 54: 497-503.

10- Yuen F, Wong K, Fung J, Ip P, But D, Hung I, et al. HBsAg seroclearance in chronic hepatitis B in Asian patients: Replicative level and risk of hepatocellular carcinoma. Gastroenterology. 2008, 135: 1192-1199.

11- Yang R, Song G, Guan W, Wang Q, Liu Y, Wei L. The Lumipulse G HBsAg-Quant assay for screening and quantification of the hepatitis B surface antigen. J. Virol Methods. 2016; 228: 39-47.

12- European Association for Study of Liver \& Asociacion Latinoamericana para el Estudio Del Higado. EASL-ALEH Clinical Practice Guidelines: Non-invasive tests for evaluation of liver disease severity and prognosis. J. Hepatol. 2015; 63: 237-264.

13- Botha F, Dusheiko M, Ritchie J, Mouton K \& Kew C. Hepatitis B virus carrier state in black children in ovamboland: Role of perinatal and horizontal infection. Lancet. 1984; 323: 1210-1212.

14- Seto K, Wong K, Fung J, Huang Y, Liu S, Lai $\mathrm{L}$, et al. Linearized hepatitis B surface antigen and hepatitis B core-related antigen in the natural history of chronic hepatitis B. Clin. Microbiol. Infect. 2014; 20: 1173-1180

15- Cornberg M, Wong W, Locarnini S, Brunetto M, Janssen A, Chan L. The role of quantitative hepatitis B surface antigen revisited. J. Hepatol. 2017; 66: 398-411.

16- Yuen F, Chen S, Dusheiko M, Janssen A, Lau Y, Locarnini A, et al. Hepatitis B virus infection. Nat Rev Dis Primers. 2018; 4: 18035.

17- Centers for Disease Control and Prevention (CDC). Use of hepatitis B vaccination for adults with diabetes mellitus: 
recommendations of the Advisory Committee on Immunization Practices (ACIP). MMWR Morb Mortal Wkly Rep. 2011; 60: 1709-1711

18- Sarin K, Kumar M, Lau K, Abbas Z, Chan $\mathrm{Y}$, Chen J, et al. Asian-Pacific clinical practice guidelines on the management of hepatitis B: a 2015 update. Hepatol Int. 2016 10: 1-98.

19- Yapali S, Talaat N, Lok S. Management of hepatitis B: our practice and how it relates to the guidelines. Clin Gastroenterol Hepatol. 2014; 12: 16-26.

20- Kim A, Lee C, Kim J, Ha Y, Park J, An $\mathrm{J}$, et al. Incidence of hepatocellular carcinoma after $\mathrm{HBsAg}$ seroclearance in chronic hepatitis B patients: a need for surveillance. J. Hepatol. 2015; 62: 10921099

21- Hosaka, Suzuki F, Kobayashi M, Seko Y, Kawamura Y, Sezaki H, et al. Long-term entecavir treatment reduces hepatocellular carcinoma incidence in patients with hepatitis B virus infection. Hepatology. 2013; 58: 98-107.

22- Tenney J, Rose E, Baldick J, Pokornowski A, Eggers J, Fang J, et al. Long-term monitoring shows hepatitis B virus resistance to entecavir in nucleoside-naïve patients is rare through 5 years of therapy. Hepatology. 2009; 49 (5): 1503-1514.

23- Murakami E, Wang T, Park Y, Hao J, Lepist I, Babusis D, Ray S. Implications of efficient hepatic delivery by tenofovir alafenamide (GS-7340) for hepatitis B virus therapy. Antimicrob. Agents Chemother. 2015; 59 (6): 3563-3569.

24- Buti M, Gane E, Seto K, Chan L, Chuang L, Stepanova T, et al. Tenofovir alafenamide versus tenofovir disoproxil fumarate for the treatment of patients with HBeAgnegative chronic hepatitis $B$ virus infection: a randomised, double-blind, phase 3, noninferiority trial. Lancet Gastroenterol Hepatol. 2016; 1(3):196-206.

25- Terrault N, Lok A, McMahon B, Chang K, Hwang J, Jonas M. Update on Prevention, Diagnosis, and treatment of chronic hepatitis B: AASLD 2018 hepatitis B guidance. Hepatology. 2018; 67 (4): 2018.

26- Papatheodoridis V, Manolakopoulos S, Liaw F, Lok, A. Follow-up and indications for liver biopsy in $\mathrm{HBeAg-negative}$ chronic hepatitis B virus infection with persistently normal ALT: a systematic review. J. Hepatol. 2012; 57: 196- 202.

27- European Association for Study of Liver and Asociacion Latinoamericana para el Estudio del Higado. EASL-ALEH Clinical practice guidelines: Non-invasive tests for evaluation of liver disease severity and prognosis. J. Hepatol. 2015; 63: 237-264.

28- Papatheodoridis V, Manesis K, Manolakopoulos S, Elefsiniotis S, Goulis J, Giannousis J. et al. Is there a meaningful serum HBV DNA cut-off level for therapeutic decisions in hepatitis $\mathrm{B} e$ antigen-negative chronic hepatitis $\mathrm{B}$ virus infection? Hepatology. 2008; 48: 1451-1459.

29- Shim H, Lee C, Kim M, Lim S, Chung $\mathrm{H}$, Lee $\mathrm{S}$, et al. Efficacy of entecavir in treatment-naive patients with hepatitis B virus-related decompensated cirrhosis. J. Hepatol. 2010; 52: 176-182.

30- Liaw F, Sheen S, Lee M, Akarca S, Papatheodoridis V, Suet-Hing F, et al. Tenofovir disoproxil fumarate (TDF), emtricitabine/TDF, and entecavir in patients with decompensated chronic hepatitis B liver disease. Hepatology. 2011; 53: 6272. 